\title{
ФОРМУВАННЯ ГУМАНІСТИЧНИХ ЦІННОСТЕЙ У ДІТЕЙ ЗАСОБАМИ ФІЛОСОФІЇ В. СУХОМЛИНСЬКОГО
}

У статті представлено проблему формування гуманістичних иінностей у дітей на основі аналізу педагогічної спадщини В. Сухомлинського. До основних засобів філософії для дітей, щяо були успішно реалізовані в Павлиській середній школі, віднесено казку, притчу, розповідь, зміст яких спрямовано на формування моральних уявлень дитини про оточуючий ї̈ світ. 3'ясовано, що філософія для дітей B. Сухомлинського трунтується на етичних засадах і дає можливість розв'язати проблеми моральноетичного розвитку в дусі гуманістичних иінностей.

Ключові слова: філософія для дітей, гуманістичні иінності, засоби філософії, педагогічна спадщина В. Сухомлинського.

Актуальність. Сьогодні світова педагогічна громадськість традиційно звертає увагу на проблеми виховання підростаючого покоління, адже останні події в світі (криза урбанізації, екологічні катастрофи, загострення міжнаціональних суперечностей і конфліктів) неодноразово демонструють зменшення вартості життя Людини, визнання ії як особистості, нівелювання іії потреб та інтересів. Це підтверджує важливість реформування освітньої сфери, зокрема грунтовну розробку ії філософського підгрунтя. Саме філософія вводить моральність у виховання, спрямовує увесь процес на формування моральних переконань, почуттів і звичок, що спираються на моральні принципи.

В центр сучасної виховної системи поставлено дитину, наділену індивідуальністю, з властивими їй інтересами, здібностями й потребами. Такий підхід потребує формування у неї гуманістичних цінностей, що за своєю сутністю є універсальним, загальнолюдськими.

Найбільш повно відповідають вимогам сучасності, сприяють поглибленню гуманістичної спрямованості виховного процесу у загальноосвітній школі теоретичні погляди і практичний досвід В. Сухомлинського з виховання всебічно розвиненої особистості. У розв'язанні завдань розвитку системи української національної освіти на сьогодні велике значення має вивчення і впровадження в життя гуманістичних ідей В. Сухомлинського, який віддав свої серце, розум, життя пізнанню, розвитку, щастю сотні школярів Павлиша. Сьогодні його педагогічні ідеї вивчає і шанує педагогічна громадськість світу.

До проблеми гуманізму в педагогіці звертались в різні часи К. Роджерс, Дж. Браун, К. Паттерсон, А. Маслоу, Ш. Амонашвілі, М. Гузик. Різні аспекти проблеми формування гуманістичних цінностей в педагогіці В. Сухомлинського були темами наукових пошуків: виховання моральних цінностей (А. Семез, Л. Бондар), формування загальнолюдських цінностей (Л. Бондар, М. Сметанський), виховання етичних цінностей (В. Ликов).

Мета статті: проаналізувати проблему формування гуманістичних цінностей у дітей засобами філософії В. Сухомлинського.

Завдання: розглянути гуманістичну педагогіку В. Сухомлинського, виділити підходи до організації навчально-виховного процесу в школі на засадах філософії для дітей В. Сухомлинського, визначити актуальність його ідей в сучасних освітніх реаліях.

Виклад основного матеріалу. Виховна система педагога пронизана ідеями людяності, гуманізму, любові, поваги до людини, високої вимогливості, розуміння серцем інших людей, співчуття і допомоги, реалізація яких відображена в 50 монографіях і книгах, 625 статтях В. Сухомлинського, а саме: "Виховання патріотизму у школярів", "Праця і моральне виховання", "Народження громадянина".

Як зазначає українська дослідниця Л. Бондар, Василь Олександрович "один із перших повернув у теорію виховання такі категорії, як совість, сором, честь і порядність, щедрість душі, моральні емоції, повагу до батьків, до дідусів і бабусь, узагалі до людей похилого віку, культ матері. Найвищі людські цінності, за Сухомлинським, становлять особистість, сім'я, колектив, народ, людство" [1: 47].

Дійсно у тоталітарному суспільстві відбулось знецінення людського життя: вивчали діяльність видатних осіб, забуваючи про власних предків. А В. Сухомлинський повертає на почесний п’єдестал родину з їі звичаями, традиціями. Він щиро вірить в духовне багатство сім'ї, невичерпні джерела народної педагогіки і мудрість батьківського виховання. "Нехай у школі (так само і в сім'ї) панують правда і довір'я" [2: 333].

У пошуках нових підходів до організації навчально-виховного процесу у школі Василь Сухомлинський на перший план ставить гуманістичні ідеї та орієнтири, що грунтуються на повазі 
особистості дитини, турботи про ії розвиток. Такий підхід передбачає визначення кожного вихованця як унікальної особистості, його прав на життя і щастя, ставлення до нього як суб'єкта власного розвитку, опору у його вихованні на сукупність знань про людину та високу педагогічну майстерність. В основу такої системи великим вченим було покладено принципи: народність, природо і культуровідповідність, гуманізм і демократизм, самостійність, активність, громадянської зрілості.

Гуманістична основа навчально-виховного процесу грунтується у Сухомлинського на положеннях про безумовну цінність і неповторність людини, іiі індивідуальну свободу і гідність, право на щасливе життя і творчість, на створення умов всебічного розвитку особистості кожної дитини. Педагогічне кредо гуманіста - безмежна любов до дітей, віра в талановитість кожної дитини, в добру іiі основу. "Віра в людину - могутня моральна сила, яка втілює в собі саму суть відносин в нашому суспільстві, ...хороший вчитель - це, насамперед, вихователь, який запалює перед вихованцями яскраве світло розуму, веде їх вперед, допомагає переборювати труднощі... хто у кожному своєму вихованцеві бачить велику людину в майбутньому" [3: 205-206].

Ідея врахування і розвиток індивідуальних особливостей і можливостей кожної дитини пронизувала всю систему життя і діяльності школи Сухомлинського:

- в своїх працях педагог виділяе завдання навчально-виховної роботи (виявити і розвивати неповторну людську індивідуальність з 1-го класу, розкрити творчі сили кожної дитини);

- основні принципи і умови розвитку дитини (любов, оптимізм, повага гідності, справедливості, підтримки, захищеність від зла, мудра вимогливість, відповідальність за кожну дитину, поблажливість до дитячого невміння та нерозуміння тощо);

- зміст навчання і виховання (зв'язок з життям, з історією рідного краю, народу, України, світу; диференціація учбової інформації в залежності від рівня розвитку, можливостей, інтересів дітей; підбір учбового матеріалу, системи занять з перспективою досягнення успіху, почуття гідності і розвитку кожної дитини);

- методику організації життя, навчання, виховання в школі, сім’ї, в навколишньому середовищі 3 перспективою виховання гідної всебічно розвинутої щасливої справжньої Людини і патріота Батьківщини.

Любов і повага, віра в добре начало в кожній дитині і висока мудра вимогливість до ії життя, бажання зрозуміти, допомогти у розвитку розуму і серця кожного вихованця, захистити від зла і навчити людяності, оптимізму, творчому підходу, активності в житті - ці і ще багато інших основ гуманізму до душі, серця, розуму, почуттів, діяльності кожного вихованця Павлиської школи. Духовним началом в мудрій людській любові Сухомлинський вважав потребу в людині, відданість один одному; поваги до людини, шанування їі свободи, доброї волі, обов'язку перед іншими людьми, державою. "Щоб уберегти себе від байдужості, треба опанувати співчуття, жалість і разом 3 тим високу принциповість i вимогливість, нетерпимість і непримиренність до зла, уміння відрізнити невинні людські слабкості від вад, що калічать душу" [4: 192].

Такі високо моральні вимоги ставив педагог перед кожним вихованцем, бо любив "не ту дитину, яка вона $\epsilon$, а ту, якою вона повинна бути", і чим складніша дитина в морально-інтелектуальному, фізичному розвитку, тим більше він любив іiі, приділяв увагу, роками створював умови для повноцінного розвитку. В роботі "Як виховати справжню людину" йдеться про моральний гуманістичний ідеал, що увібрав в себе найкращі риси менталітету українського народу. Педагог розкриває конкретні принципи, істини, повчання, настанови, рекомендації щодо гуманістичного виховання і становлення кожної дитини (Чотирнадцять законів дружби, Десять правил не можна, Десять негідних речей і т.д.), що й становлять "педагогічну систему, яка може бути взірцем органічного поєднання національних традицій із загальнолюдськими цінностями" [5: 122]. Бо формування ставлення до людини повинно починатися 3 раннього дитинства з любові і поваги до батьків, до представників старшого покоління, до рідних, до оточуючих, до людей, що потребують допомоги.

Тільки в роботах Сухомлинського є такі гуманні розділи як "Розуміння життя, добра і зла в ньому", де найвищою цінністю визнано життя людини, в якому є щастя і горе, біда і страждання, радість, тривога i біль душі. Цьому теж треба вчити кожну дитину, готуючи іiі до життя серед людей, до гідного місця в суспільстві. "Духовний зв'язок з людьми, почуття співучасті в ділах і пристрастях людських, одухотворення радостями людськими і страждання горем близьких і далеких своїх співвітчизників - таке ж щастя, як чисте повітря; осягає людина це щастя найглибше тоді, коли втрачає його. Мудрість виховання полягає в тому, щоб людина дорожила цим щастям тим більше, чим більше його має. Страшною бідою є порожнеча душі. Це значить, що в людини немає нічого святого за душею, нічим вона не дорожить і нічому не поклоняється" [6: 224]. Байдужість, безвільність, пасивність - це вже шлях до зла, яке починається з етичної неграмотності, з незасвоєння азбуки людської культури, що примножує справедливість, гідність, велич, щастя кожної людини.

Аналіз педагогічної спадщини В. Сухомлинського дає змогу розглядати родинно-шкільне виховання як складову школи гуманності. На думку педагога-новатора, умова співпраці сім'ї та школи є однією 3 
найважливіших для виховання всебічно розвиненої особистості. Постійно використовуючи i поповнюючи надбання народної педагогіки, він відродив і започаткував у Павлиській школі багато свят. Адже школа стає осередком культури, якщо в ній панують чотири культи: Батьківщина, Людина, Матір і Рідне Слово, які шанують і в родині.

Важливою складовою виховної системи В.Сухомлинського є патріотичне виховання дітей, бо серцевина людини - любов до Батьківщини - закладається в дитинстві. Він підкреслював, що Батьківщина - це не абстракція, не відхилене поняття, а жива дійсність, реальні люди, в числі яких і ми, кожний вчинок проти неї є вчинком проти самих себе. Ми - в Батьківщині, а Батьківщина в нас. Без цього немає цілісної особистості, немає цілісного характеру. Ми тим більше пізнаємо самих себе, чи м щедріше віддаємо себе Вітчизні, одночасно вбираючи іiі щедроти і повертаючи їй набагато більше. Патріотичне виховання в Павлиській школі, як і кожен напрямок, проходило через серце - розум - руки кожної дитини. Всі діти брали активну участь в добрих справах для школи, сім'ї, села, країни, людей світу. Наприклад, кожний учень вирощував за 10 шкільних років 100 дерев, пов'язаних з різними ритуалами і традиціями: алеї пам'яті героїв і дружби, дубовий гай героїв, куточки краси, розарії. Ця діяльність особливо благодатно впливала на виправлення душ важких дітей, піднімала їх гідність, значимість їх життя і діяльності для радості і щастя інших людей.

Велике значення в розвитку дитини мала праця. Дуже мудро Василь Олександрович знаходить виховні коріння дитячої праці в прадавніх традиціях українського народу: "Найвища педагогічна мудрість трудового виховання полягає в тому, щоб утвердити в дитячому серці народне ставлення до праці. Праця для народу є не тільки суттєвою необхідністю, без якої немислиме людське існування, та й сферою багатогранних проявів духовного життя, духовного багатства особистості. В праці розкривається багатство людських стосунків. Виховати любов до праці неможливо, якщо дитина не відчуває краси цих стосунків. В трудовій діяльності народ бачить найважливіший засіб самовираження, самоутвердження особистості. Без праці людина стає порожнім місце, говорять у народі. Важливе виховне завдання полягає в тому, почуття власної гідності, особистої гордості вихованця грунтувалося на трудовому успіху" [4: 239]. Особливо важлива роль радісної творчої праці для дітей, які відстають у розумовому розвитку. Для них праця і успіх в її результатах - стежка для розвитку пам'яті, думки, розуму, логічного мислення.

Через творчу, емоційно насичену, одухотворену гуманізмом і радістю успіху працю, за думкою педагога, можливо і необхідно всебічно розвивати кожну дитину, особливо ту, яка має якісь недоліки в розвитку. Триєдність виховання через серце $\rightarrow$ розум $\rightarrow$ руки дитини для важких дітей, за Сухомлинським проходить через серце $\rightarrow$ руки $\rightarrow$ розум. Через працю відбувається розвиток задатків здібностей, інтелекту, почуття людської гідності, щастя людського життя. Це особливо важливо для дитини, обділеної в чому-небудь долею. В Павлиській школі для цього були створені всі умови: діти вирощували хліб і сади (по традиції навесні учні 1-го класу садили "Сад матері"), кожна дитина за шкільні роки вирощувала 100 дерев (це було пов'язано з різними традиціями), конструювали діти моделі машин і механізмів (48 гуртків в школі), доглядали тварин, будували теплиці, майстрували, працювали в полі, вивчали с/г техніку тощо.

Різнобічний розвиток кожної дитини проходив і через естетичне виховання: малювання, співи, слухання музики і звуків природи, гра на музичних інструментах, художньо-творча самодіяльність. Вони милувалися і творили красу в своїй душі і в довкіллі для людей, країни, майбутнього.

Процес пробудження і формування дрімаючих сил дитячої душі, серця і розуму, за Сухомлинським, проходив складний шлях: спостереження $\rightarrow$ здивування перед довкіллям (емоції, уява) $\rightarrow$ цікавість, допитливість, інтерес, прагнення пізнати світ (музика, малювання, казка, читання, творчість) $\rightarrow$ розвиток розуму, здібностей (праця, навчання, радість успіху творення краси і добра для людей і природи, щасливе повноцінне життя кожної Людини).

Висновки. В гуманістичній педагогіці В. Сухомлинського в центрі уваги неповторна дитина, іiі особливості, умови життя і розвитку, виховання справжньої щасливої Людини і Громадянина України.

Безсумнівно, досвід В. Сухомлинського і розроблені ним методики становлять значний науковий i практичний інтерес, розширюють наукові уявлення про багатоманітність світових ідей і методик, спрямованих на розвиток мислення дитини, формування в неї пізнавальних i етичних уявлень $\mathrm{i}$ орієнтирів.

Подальшого вивчення заслуговують неопубліковані праці та публіцистика В. Сухомлинського 3 питань гуманізації та демократизації навчання та виховання учнів, історіографія та дослідження питань сімейного, трудового, естетичного, правового виховання молоді з позиції педагогіки гуманізму.

\section{СПИСОК ВИКОРИСТАНИХ ДЖЕРЕЛ ТА ЛІТЕРАТУРИ}

1. Бондар Л. С. Загальнолюдські цінності у спадщині В. Сухомлинського / Л. С. Бондар // Шлях освіти. - 1997. - № 2. - С. 47-49.

2. Сухомлинський В. О. Духовний світ школяра / В. О. Сухомлинський // Вибр. тв. : В 5т. - К., 1976. - Т. 1. C. $209-400$. 
3. Сухомлинський В. О. Людина неповторна / В. О. Сухомлинський. - К., 1962.

4. Сухомлинський В. О. Серце віддаю дітям / В. О. Сухомлинський // Вибр. тв. : В 5 т. - К., 1977. - Т. $3 .-$ $670 \mathrm{c}$.

5. Мухин М.И. Гуманистические традиции и новаторство в педагогическом опыте В. А. Сухомлинського : автореф. дис. на соискание уч. степени док. пед. наук / М. И. Мухин. - М., 1995. - 69 с.

6. Сухомлинський В. О. Як виховати справжню людину / В. О. Сухомлинський // Вибр. тв. : В 5 т. - К., 1976. Т. 2. $-670 \mathrm{c}$.

7. Сухомлинська О. Філософія для дітей як педагогічна проблема / О. Сухомлинська // Психолого-педагогічні проблеми сільської школи. - 2002. - № 2. - С. 8-19.

\section{REFERENCES (TRANSLATED \& TRANSLITERATED)}

1. Bondar L. S. Zagal'noliuds'ki tsinnosti u spadshhyni V. Sukhomlyns'kogo [Universal Human Values in the inheritance of V. Sukhomlynsky] / L. S. Bondar // Shliakh osvity [Way of Education]. - 1997. - № 2. - S. 47-49.

2. Sukhomlynsky V. O. Dukhovnyi svit shkoliara [Spiritual World of a Pupil] / V. O. Sukhomlynsky // Vybr. tv. :V 5 t. [Selected Works : in 5 Volumes]. - K., 1976. - T. 1. - C.209-400.

3. Sukhomlynsky V. O. Liudyna nepovtorna [A Person is Unique] / V. O. Sukhomlynsky. - K., 1962.

4. Sukhomlynsky V. O. Sertse viddaiu ditiam [I Give My Heart to Children] / V. O. Sukhomlynsky // Vybr. tv. :V 5 t. [Selected Works in 5 Volumes]. - K., 1977. - T. 3. - $670 \mathrm{~s}$.

5. Mukhin M. I. Gumanisticheskiie tradytsii i novatorstvavo v pedagogicheskom opyte V. A. Sukhomlynskogo [Humanistic Traditions and Innovation are in Pedagogical Experience of V. Sukhomlynsky] : avtoref. dis. na soiskaniie uch. stepeni dok. ped. nauk. - M., 1995. - 69 s.

6. Sukhomlynsky V. O. Yak vykhovaty spravzhniu liudynu [How to Bring up the Real Man] / V. O. Sukhomlynsky // Vybr. tv. :V 5 t. [Selected Works in 5 Volumes]. - K., 1976. - T. 2. - $670 \mathrm{~s}$.

7. Sukhomlynska O. Filosofiia dlia ditei yak pedagogichna problema [Philosophy for Children as a Pedagogical Problem] / O. Sukhomlynska // Psykhologo-pedagogichni problemy sil's'koi shkoly [Psychological and Pedagogical Problems of a Rural School]. - 2002. - № 2. - S. 8-19.

\section{Сараева Е. В. Формирование гуманистических ценностей у детей средствами философии}

\section{В. Сухомлинского.}

В статье представлена проблема формирования гуманистических иенностей у детей на основе анализа педагогического наследия В. Сухомлинского. К основным средствам философии для детей в Павлылской средней школе отнесены сказка, притча, рассказ, содержание которых направлено на формирование нравственных представлений ребенка про окружающий его мир. Определено, что философия для детей

Сухомлинского опирается на этические основы и дает возможность решать проблемы моральноэтического развития детей в контексте гуманистических иенностей.

Ключевые слова: философия для детей, гуманистические ияенности, средства философии, педагогическое наследие В. Сухомлинского.

\section{Saraieva O. V. The Formation of Children's Humanistic Values by Philosophy of V. Suhkomlynsky.}

The article presents the problem formation of the children's humanistic values on the basis of the analysis of

$V$. Sukhomlynsky's pedagogical heritage. The main means of philosophy for children that have been successfully implemented in Pavlysh secondary school include a fairy tale, a parable, a narrative, the content of which is aimed at shaping the child's moral ideas about the surrounding world.

The purpose of the research is to analyze the problem of the formation of children's humanistic values by means of philosophy of $V$. Sukhomlynsky.

Objective: to analyze the humanistic pedagogy of V. Sukhomlynsky, to identify approaches to the organization of the educational process in the school on the principles of philosophy for children of $V$. Sukhomlynsky, to determine the relevance of his ideas in contemporary educational realities.

The philosophy of $V$. Sukhomlynsky for children, based on ethical principles, makes it possible to solve the problems of moral and ethical development in the context of humanistic values.

The ideas of the uniqueness of the child, the consideration and development of its individual peculiarities and abilities pierced the entire system of life and activity of the V. Sukhomlynsky's school: the tasks of educational work (to discover and develop a unique human personality from the $1^{\text {st }}$ grade, to reveal the creative forces of each child); the basic principles and conditions of the child's development (love, optimism, respect for dignity, justice, support, protection from evil, wise demandingness, responsibility for every child, indulgence in childhood inability and misunderstanding, etc.); the content of education and upbringing (connection with life, with the history of the native land, people, Ukraine, the world; differentiation of educational information depending on the level of development, opportunities, interests of children, selection of educational material, systems of occupations with the prospect of success, sense of dignity and the development of each child); the 
methodology of organization of life, education, education in school, family, in the environment with the prospect of education of a well-developed, happy, true Human and patriot of the Motherland.

The philosophy of $V$. Sukhomlynsky for children significantly influenced the emotional and aesthetic development of children of all ages. For this, the teacher used such means of education as nature, music, fairy tale, artistic word and environment.

Key words: philosophy for children, humanistic values, means of philosophy, pedagogical heritage of V. Sukhomlynsky. 